\title{
Diversity and elite religiosity in modern China A model
}

$\mathrm{T}$ his article looks at religious diversity among late imperial and modern Chinese elites; by contrast with most of the existing literature, which looks at correlations between social class and religiosity, this article adds the dimension of the exercise of personal choice and agency in the context of a vast and variegated religious repertoire. After reviewing existing theoretical models, it argues for the importance of two factors: a level of commitment to religious practices, in both the public and private realms, and knowledge (about the religion of others, whether one engages in such religion or not). It then charts these two factors on a graph onto which individuals can be placed, and thus grouped into types. These types represent a new and fruitful way of thinking about religious diversity.

The REVOLUTIONARY REFORMS OF 1898 launched modern China, in matters religious as well as in every other aspect of social and intellectual life (Goossaert 2006). Even though these reforms were short-lived, the subsequent attempts at reforming the empire and then the Republican state policies were all inspired by the vision which had informed them. From this point on, a growing estrangement seems to have taken place between the elites and popular culture, in particular with regard to the latter's religious aspects. This estrangement took very different forms, from an all-out westernization to a radical reinvention of Chinese identity that excluded whole realms of culture; it resulted in a violent propaganda campaign against 'superstitions' and repressive policies that caused the destruction of many temples, bans on festivals and rituals, and paved the way for the post1949 attempted eradication of most aspects of lived religion.
Certain historians consider that these conflicts find their roots in earlier periods and the long-standing tension between elite Neo-Confucian culture and popular religion. Other historians, however, also note that, not unlike prerevolutionary societies in early modern Europe, the Qing (1644-1911) elites had also maintained a biculturality that allowed them to participate in both the culture (religious and otherwise) proper to their milieu and to that of the society around them (Sutton 2000: 23-4). This biculturality extends to many realms, including language (local vs. Mandarin), food, performing arts, rituals and cults. The ruptures of modernity would then have been accompanied by a decline of such biculturality, and resulted, among the elites, in a complete misunderstanding of, and deep aversion to, the religious practices and worldviews of the lower classes - a misunderstanding and aversion which is still in evidence today, albeit obviously highly dependent on variables such as personal life histories and place of residence.

At the same time, estrangement from popular culture does not mean an overall decline in religiosity among modern elites: far from it. Republican (191249) elites sustained a high level of religious commitment that should be analysed in terms of both certain continuities with the late imperial period, and multifarious forms of reinvention and innovation (Katz and Goossaert 2015). My purpose here is to explore ways of thinking about the personal religious worlds of the elites, and not their public activities or their philosophical pronouncements. I propose to build a model for producing an analysis of late imperial elite religiosity that could be further used for tracing developments in the post- 1898 period and also to develop comparisons with other cultural spheres (these not being the objects of the present article). 
This, I propose, is a useful way to look anew at religious diversity in the Chinese context. Most of the attention, when the issue of diversity is raised (Schmidt-Leukel and Gentz 2013) has been focused on institutional plurality, with the framework of the 'three teachings' - Daoism, Confucianism, Buddhism - as a triple orthodoxy and its connections to sectarian traditions and popular/local/vernacular/ common religion. Much debate has already taken place on the relation of the clerical, institutional traditions of the three teachings and the rest of the religious field, and the category of 'popular religion' (Clart 2007). Geographical variation has also become a focus of research of late, giving space to a consideration of social strata as well as an ethnic dimension in the debate on cultural and religious homogeneity (or the mere semblance thereof) in late imperial and modern Chinese culture (Sutton 2007).

The approach adopted here, while also sensitive to correlations between social class and religiosity, adds the dimension of personal choice and agency in negotiating a vast and variegated religious repertoire. This does not mean I am adopting rational choice theory (the chief advocate of which in the Chinese context is Yang Fenggang, see Yang 2012). While this theory's relevance to the situation in contemporary China is debated (Palmer 2011), it is certainly largely irrelevant for earlier periods. For certain particular religious practices, there existed a market and people made individual choices (Goossaert 2011a); most religious choices, however, were collective. Furthermore, access to religious goods and services was heavily regulated, including for elites, not so much by the state but by local communities (Goossaert 2013). For these reasons, I insist on distinguishing between diversity and choice of religious affiliation as two distinct theoretical issues. Rather, I see diversity in modes of religious coexistence between different traditions, but even more between different styles, sensibilities and levels of commitment. While elites' religious lives differed in style from those of nonelites, the question of diversity is largely that of their articulation with other styles.

\section{Late imperial elites}

To explore the above issues requires a better understanding of the religious practices and attitudes of the elites and their connection to those of the society around them before 1898 . Were elites in the last years of the Qing already alienated from the religion of the people, so that they only waited for a favourable political context in order to participate in its repression? Or were they, to the contrary, maintaining connections, not necessarily warm, but nonetheless close, natural and regular ones, with the temples, cults and rituals around them? To what extent were the various types of elites (such as urban upper elites vs. ruralbased local gentry) factors in such differences? How did the post- 1898 new political and social conditions affect such connections, at the level of both social and private lives?

Such questions raise numerous methodological issues. First, the term 'elites' suggests a certain cultural homogeneity that on closer examination proves rather elusive. Internal differences are quite notable between upper elites (the jinsh $i$ 進士, i.e. laureates of the highest level of civil service examinations, almost all of them officials, active or retired), who adhered quite closely to Confucian norms and practices, and the middle and lower gentry (who had passed the first or second level but usually did not gain access to officialdom), whose religious identities were more varied. Together they formed the shensh $i$ 紳士 (usually translated as gentry), a legal category privileged by the imperial state. These various strata of elite society were less differentiated according to education than social role, active officials having to enforce imperial laws, which were quite repressive in religious matters - even though in practice tolerance and negotiation were the dominant mode of relationship between state agents and local religious groups (Goossaert 2014a). Members of the gentry not being employed by the state were much freer to interpret and enact their role as educators of the people (jiaohua 教化). Among the latter, one finds local notables who played leadership roles within local religious structures, but also activists (people who by personal choice devoted themselves to a moral/religious cause, and invested a large proportion of their resources into it) trying to reform local religious practices. Some of the activists were fundamentalists, that is, people who dreamt of returning to the fantasied golden age described by the classic texts and wanted to abolish all later ritual, practical and theological accretions not warranted by them. Others (even though distinctions were never so clear-cut) had a more inclusive approach, often tied in to the practice of spirit-writing (fuji 扶乩, feiluan 飛鸞, direct written revelations from the gods), the writing and diffusion of morality books, 
and philanthropy.

Furthermore, economic elites were closely allied to the gentry but might, as such, have had their own distinct religious activities; the leaders of the major guilds, who largely controlled civic life in the cities, organized the great festivals and processions (saihui 賽會) that irked the officials and fundamentalist activists. To further complicate the picture, the upper strata of the Daoist and Buddhist clergies were full of members of the local elites, engaging in the same cultural pursuits (painting, calligraphy, poetry) and coenforcing local regulations. To put it in a nutshell, late imperial elites had about as much religious plurality as society as a whole.

The historiography so far has largely focused on state policies towards religion and their impact, rather than the convictions and worldviews that informed such policies and the pronouncements of the officials. Various theoretical and methodological tools have been applied, or at least proposed, in performing such a task. Among such tools, formal religious affiliations are not really relevant here, as elites were defined ex officio as 'Confucian' ( $r u$ 儒) while they also followed the state in recognizing (to various extents) the validity of Buddhist and Daoist teachings. Similarly, 'faith' or 'belief' are hardly useful as a category, as sources rarely addressed religious involvements in such terms. The notion of piety is more useful; it allows us to focus our attention on the sensibility, style and aesthetics and the concrete ways in which one engages in or with religion, including in informal settings. The aesthetic dimension is crucial in this concept, and sheds light on how elites self-identified with practices (meditation, moral selfimprovement, highly scripted liturgy, etc.) characterized by self-control, solemnity, and restraint, in explicit contrast to what was described as the exuberant style (excess of colours, sounds, expenses, etc.) of 'popular' practices.

Another, related concept, 'modalities', also usefully cuts across confessional religious identities (Confucian, Buddhist, Daoist, etc.); Adam Y. Chau distinguishes between five modalities of doing religion within Chinese (and other) societies: discursive (text-based); relational/organizational (organizing festivals, running temples), personal (self-cultivation, body techniques), liturgical, and immediate/practical (Chau 2011). The practices of modern Chinese elites certainly resort to several of these modalities: some elites devoted themselves to a discursive, exegetical mode, as they read and commented upon large numbers of religious texts while declining as much as possible to take part in public religious activities, while others favoured the organizational modality, through moral activism (distributing morality books, public teaching and preaching, charitable activities and so on).

Useful as they are, the two concepts of piety and modality mostly allow us to apprehend the conceptions and practices of the most religiously-involved elites: the activists. Yet, in China as elsewhere, the degree of interest and involvement in things religious was highly variable: some people had a sustained personal practice and were active in religious organizations, while others had a limited interest in such things, participating when they had to, with little personal commitment. A third concept, religious knowledge, ${ }^{1}$ is necessary at this point of our theoretical construct in order to bring into the analysis the large numbers of elites who had little visible religious involvement. By religious knowledge I mean what actors knew and understood about religion, and the vocabulary they used to discuss it, which includes conceptions and practices that are not those of the actors themselves, but that they see and understand (or not) among the people around them. Focusing on religious knowledge allows us to also ask the question of what elites ignored or misunderstood, what were the limits to their capacity to understand and participate in the society around them, and to probe the issue of the modern distance between popular and official culture and religion.

I propose for our present purpose to define religiosity as the sum of the three concepts briefly outlined above - religious knowledge, piety, and the modality of religious enactment: that is to say, what individuals knew, felt and did. Defined thus, the notion opens windows on differences between various members of the elites - differences that are linked to context (historical, local, familial) but also to individual choices and preferences.

\section{Public and private religiosities}

Understanding any person's religiosity involves distinguishing between different spheres, spanning the spectrum from official to public, to familial,

1 In an earlier publication in French (Goossaert 2011b), I used the term 'culture religieuse'. 
to intimate. One must be careful when discussing public and private in the late imperial context, when they were defined in ways markedly different from what we know from contemporary experience. Furthermore, late imperial culture was imbued with a strong, age-old conviction that one's public actions reflected the quality of one's private moral cultivation. Yet a number of practices were compartmented: an official could engage at ease in Buddhist or Daoist self-cultivation, as long as he did not discuss it in his capacity as an official.

Religiosity in public life was largely defined by mandatory practices and observances, imposed either by law, custom or etiquette. Late imperial sitting officials had to attend a very high number of sacrifices all year long, and were also obliged to visit fixed lists of temples on a regular basis; for instance, they went to the City God Temple, Chenghuangmiao 城隍廟, twice a month. Students also had to participate twice a month in rituals in the Confucius temple. Besides this, officials and many other members of the elites were invited to all major local festivals, and could hardly systematically decline. They also had to attend family and lineage rituals of their kin and their social network. Very often, they were invited to take an active role in such celebrations, being for instance invited to perform the consecration of the soul-tablet of a deceased. More generally, literati who had passed the first degree of the examinations, and were thus part of the gentry, were qualified to act as performer of Confucian rituals, lisheng 禮生. Some poor scholars, or from families specialized in Confucian ritual, made a living from their liturgical expertise; many more engaged it on a more occasional basis (Liu Y. 2013).

Browsing through the diaries of late Qing scholars, one realizes the pervasiveness of this social religious life. Arguably in many, if not most, cases participating in such rituals was routine, and did not imply a deep emotional or spiritual involvement on the part of the participants, who would be waiting for the end of the ritual for an opportunity to chat with their kin, friends or colleagues around the banqueting table. Yet, one cannot deny that these rituals could induce meaningful religious experiences, and that they informed, possibly passively and unconsciously, the habitus and worldviews of those who had to attend them so often. At the very least, they nourished the literati's liturgical culture.

Another type of participation in local religious life concerns the role of elites in community religious institutions, notably the management of the large temples. Historians tend to assume that elites gradually retreated from this role at the end of the imperial period, but no study yet documents in detail the chronology, causes and scope of this phenomenon. ${ }^{2}$ Merchants remained deeply involved in the management of urban temples into the first decades of the twentieth century, showing a case of partial continuity across the revolutions. Even when not active in the management of the temples, members of the elites continued to be called on to write inscriptions for temples and monasteries (literary patronage), which requires some knowledge of the cults and traditions involved; similarly, many literati were involved in the compilation of local gazetteers and other essays in local history, which necessarily dealt with local cults and ritual culture. Furthermore, elite activists were managing their own charities, shantang 善堂 and religious associations, which organized Confucian, Daoist and Buddhist rituals.

Beside this social religious life, the literati had, to a highly variable degree, a private religious life, chosen and characterized by more intense spiritual involvement. Some of them were lay Buddhists. Perhaps the best known in the existing scholarly literature is Peng Shaosheng 彭紹升 (1740-96), a jinshi and a member of the extremely prestigious Suzhou Peng lineage, who has left a legacy of many influential works in both the classics and Buddhism. ${ }^{3}$ Others chose to immerse themselves in Daoist selfcultivation techniques, notably inner alchemy, taking an active part in the writing, editing and distribution of manuals, and teaching to a few selected disciples (Goossaert 2007: 283-97). Such Daoist self-cultivators were by no means recluses: consider the case of the famous Daoist-cum-businessman-cum-reformist

2 Susan Naquin (2000), David Faure (2007) and Michael Szonyi (2002) have all documented how local elites have massively invested in certain institutions (lineages, charities) in late imperial times, often, but not always, to the detriment of local temples. There are however counter-examples where local elites did reinforce their involvement in community temples during the nineteenth and early twentieth centuries (Katz 2003). On the case of the City God temples, especially in the context of the postTaiping reconstruction of communal institutions, see Goossaert 2015a.

3 On the religious culture of the prestigious Suzhou Peng family, see Burton-Rose 2016. 
intellectual Zheng Guanying 鄭觀應 $(1842-1921) .{ }^{4}$ Buddhist meditation and Daoist inner alchemy were part of a larger set of spiritual techniques that come up (usually only in a very allusive manner) in the writings of the literati, whereby they controlled their minds and bodies, dealt with dangers and the presence of spirits, and with illnesses by means of recitation of incantations ( $z h o u$ 咒), visualizations, divination, devotional rites, penance, meditation (jingzuo 靜坐), and so forth.

One of the most widespread and influential of such techniques was the practice of spirit-writing which lay at the core of the religious lives of late imperial elites, in both private (homes) and public (temples) settings. ${ }^{5}$ Morality books (shanshu 善書) revealed by spirit-writing constitute the largest part of the production of religious texts by elites since around the sixteenth century; these books carried a vision of educational, charitable and moral reform, but also had a strong devotional dimension concerning saviour deities, notably Wenchang, Guandi 關帝 and Lü Dongbin 呂洞賓 (Goossaert 2015b). Some of these productions defined religious practices explicitly linked to the literati, such as the cult of written characters, xizi 惜字.

Indeed, far from exposing a 'secular' ethics, the omnipresent spirit-writing cults and attendant moral reform movements were developing a vibrant eschatology, whereby literati were entrusted with saving the world from impending apocalypse (Goossaert 2014b). When the apocalypse did seem to have arrived, in the form of the unprecedented massacres and chaos of the Taiping war (1851-64), it is with these tools that many literati made sense of the events, and they resorted even more energetically to spirit-writing and moral proselytizing (Goossaert 2016). Movements of religious and cultural revitalization which emerged then were to continue into the twentieth century; they constituted a major case of continuity between the late imperial and the Republican elite religious worldviews (Yau 2005; Wang C. 2015). Linked to these eschatological scenarios was a deeply-held aspiration to self-divinization (Goossaert 2017). Late imperial elites, quite

4 On Zheng Guanying's involvement with Daoist selfcultivation and spirit-writing, see Fan C. 2010; Liu X. 2009: 22-3.

5 On modern spirit-writing groups, see Katz 2015a; Fan C. 2015. independently of being transformed into ancestors by their kin, aspired to become gods as members of the divine bureaucracy, and had great confidence that they would be nominated as a City God or other such position (Clart 2003, Jordan and Overmyer 1986).

Studies of the activist milieus such as those who ran spirit-writing cults and published their revelations is obviously crucial for our understanding of the religious world of late imperial elites, but it should not finesse the question of the rest of the elites. What proportion of the elites were participating in spirit-writing séances, and were actively involved in the other activities of the shantang? What proportion read the spirit-written revelations and morality books? We know of the activists by their publications (including spirit-written texts and their paratexts: prefaces, notes and appended records), but other elite members also left traces of their individual religious worlds in their private writings. In an innovative work, Liu Xun studied the artistic and poetic productions of the literati in an aristocratic Manchu family, the Wanyan 完顏, that provided the Qing state with officials for each generation until the late nineteenth century; Liu demonstrated the importance for these literati-officials of a Daoist vision of the world, expressed in poems, that helped them make sense of the vicissitudes of their careers, and found an outlet in the worship of the immortal Lü Dongbin (Liu X. 2004). Another major textual resource, already mentioned above, is that of diaries and autobiographies. Henrietta Harrison, whose study of the diary of Liu Dapeng 劉大鹏 (1857-1942), a poor provincial laureate (juren) from Shanxi, is particularly enlightening: this scholar, as he represents himself in his daily notes, sees the moral retribution of actions at work at every turn of events, and is certain every time he encounters a setback that Heaven is punishing him for his sins. This man, considered by the local population as an exemplary Confucian, is highly pious, regularly visits the local temples, and meets Confucius in a dream (Harrison 2005). This shows to what extent literati training and religious habitus were closely interwoven.

\section{Writing about religion}

Whereas personal texts such as poetry and diaries express an intimate religious world, chosen and not confrontational, other genres by contrast allow the literati to pass judgment on the religious culture of 
others. The Chinese press, as it appears in the 1870s, played an active role in carrying such judgments, notably the best known of the daily newspapers, the Shenbao, published in the Shanghai concessions from 1872 until 1949. One finds in the Shenbao a very large number of reports describing local religious life in Shanghai and other major cities (including spirit-writing activities), and anecdotes on the extraordinary (healings, exorcisms, miracles, strange apparitions), but also a highly developed polemical discourse, often anticlerical and occasionally hostile towards the large community rituals (Goossaert 2002a, 2002b). Such polemics are important not only as they prefigure elite attacks on popular religion as they unfolded from 1898 onward, but also as they express various levels of understanding of, and familiarity with, the religious ideas and practices under attack.

One more genre opening a window on the religious worlds of late imperial elites is the anecdotes (biji 筆記) and notably those devoted to the 'records of the strange' (zhiguai 志怪). In a separate publication, I have developed a case study of one very prominent late Qing intellectual, Yu Yue 俞樾 (18211906), to explore his religious knowledge, based on his large collection of anecdotes, the Youtai xianguan biji 右台仙館筆記 (Goossaert 2011b). Yu is interesting because he is not an activist, and he himself states quite clearly that his private religious life was less intense than that of many of his peers, friends and relatives. He did author two commentaries on religious classics (one Buddhist, one Daoist), but these are minor items in his overabundant oeuvre. However in the Youtai xianguan biji Yu documents his sustained interest in local religious culture, which he knows to an important extent through his female relatives (mother, wives, daughters, daughters-inlaw, servants) who themselves are active participants in local religious life. Yu could be critical of vernacular rites and specialists but not systematically, as he also has a nuanced discourse on spirit-mediums. He readily admits that the world he lives in is saturated with ghosts and spirits, but thinks upright scholars are superior to them because 'a righteous person cannot be overcome by wickedness'. Yu is interested in the multifarious spiritual techniques used by his friends and students; he does not himself engage in spirit-writing, but many people around him do. Like so many other authors, Yu dismisses some cases as frauds, but not on principle. Last but not least, Yu accepts as a matter of fact that scholars become gods; most of his deceased kin and friends have acknowledged postings in the other world.

Due to his being anchored in a rural, domestic universe and territory, Yu has some familiarity, even though it is not always sympathetic, with the religious world of the common people; he thus considers that the religion that unfolds around him is comprehensible. As a member of the elite, he takes very seriously his role as a moral authority, but he mostly writes as a benevolent observer rather than a fiery reformer of 'popular' practices. One generation later, many scholars will describe the same world of popular cults, rites and specialists as altogether absurd and alien. Yet, we should not overstate rupture over continuity: Yu does not participate in local religious life beyond domestic activities. He apparently hardly ever goes to temples and festivals. He does not chronicle these cults and festivals as folklorists do, and it does not seem to him a particularly important aspect of culture worth preserving. Yu thus appears as a link between classical culture and the early twentieth-century redemptive societies that will reformulate and revitalize the Chinese spiritual heritage, and in which several of Yu's students will be active (Goossaert and Palmer 2011: chapter 4). His religious vision is in line with the 'popular Confucianism' described by Philip Clart (2003), which was based on a social stratum of educated people aspiring to become gods, and to bringing back moral order to the world. Yu shares with them a conception of holiness based on self-discipline and moral self-cultivation, and their steadfast conviction of the spiritual superiority of the scholars.

\section{A model of elite religiosity}

Based on the above considerations, I would like to propose a simple model of Chinese religiosity, valid across time, that would chart members of the elites according to two key parameters than seem most heuristically important: commitment and knowledge.

Commitment means the degree to which a given individual devotes an important part of her time, energy and resources (both material and symbolic) to religious activities and endeavours; as discussed above, high levels of commitment can be invested in either the public or the private realm, or both. It has been remarked repeatedly that in pre-1911 China (and even after that) any distinction between religious and non-religious institutions and activities is very moot. 


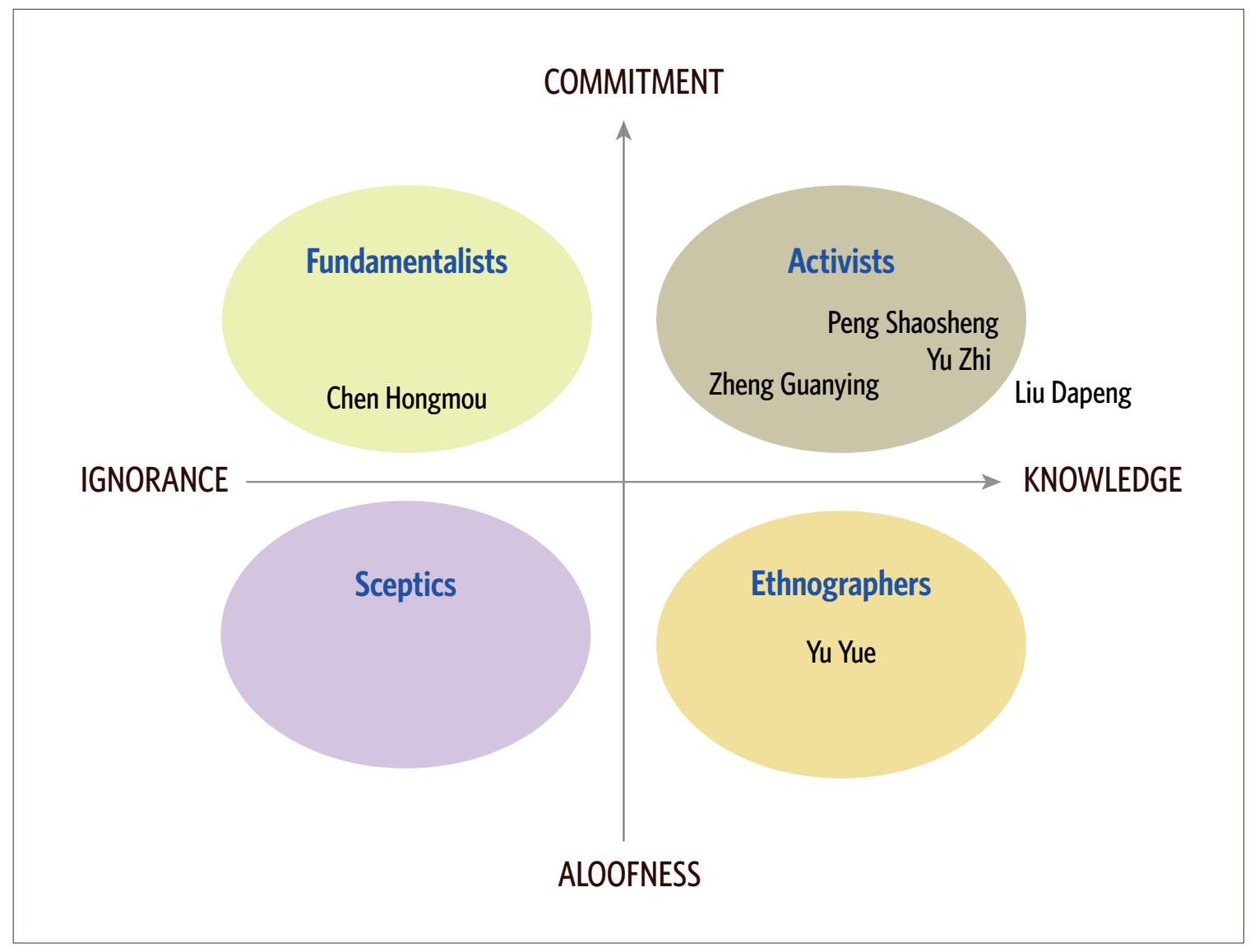

Fig. 1. Types of elite religiosity; charting selected late Qing individuals.

Still, humans have by character and training widely varying appetites for rituals, cults and other religious activities, and among modern Chinese elites, there is a clear gradient between people who seem to have, or indeed admit to having, little patience for performing sacrifices, listening to sermons, and meditating, and those who confess and profess a strong attraction to such activities. Keeping in mind that commitment varies according to the modalities (intense meditators can eschew participation in temple management), I give a high mark to those individuals who devote time and money to such activities as setting up associations or temples, organizing rituals, writing, editing, and publishing religious books.

The second parameter is knowledge of religious culture, which I have defined above as an interest in things religious and an expressed understanding of one's religious context, whether the individual in question participates in it or not.

If we set these two parameters as the axes of a chart, and start to place individuals accordingly (this is, admittedly, a subjective exercise), then patterns and clusters begin to appear, which we can theorize as ideal types. It bears pointing out that the two axes are independent - which sets my chart apart from Bourdieu's chart of the religious field, where the axes of capital and power are interdependent. One of the benefits of such an exercise is that it allows for the clustering of people who may have lived different lives, and have practised rather different types of religion, but who nonetheless exhibit rather similar attitudes towards the religious.

Let us look at clusters that form in the four quadrants of our chart - remembering that most people tended to congregate somewhere in the middle, as in any such chart. Top left are people with a high level of commitment, but a low level of knowledge; I call them 'fundamentalists': people intensively engaged with their own particular tradition, but willfully ignorant, and usually rather dismissive, of other traditions and forms of religious practice.

Top right are people both engaged and cultured: I deem them 'activists', as many activists tend to have broad interests and to participate in groups (such as spirit-writing cults) that cover a large spectrum of religious convictions. It is important to emphasize 
how much agency elites had in fashioning engaged religious lives, thus creating a highly diverse social landscape; the choice between engaging or not engaging, but also between innumerable and very different religious groups (for example, clergy-led or anticlerical, pietistic or socially engaged, conservative or eschatological) vying for their commitment. Consider for instance Yu Zhi 余治 (1809-74), an extremely engaged Jiangnan scholar who wrote, printed and disseminated religious tracts in many genres (theatre, vernacular ballads, tracts in classical Chinese), and was famous for his charitable activities. During the Taiping war, Yu Zhi lived as a refugee collecting funds for the loyalist armies and militia, organizing anti-Taiping propaganda, and relentlessly preaching in public, exhorting people to repent and engage in moral reform so that the gods may be appeased and peace return to China (Meyer-Fong 2013: chapter 2). Peng Shaosheng, mentioned above, is another good example, being both a devoted Buddhist, and an active participant in spirit-writing cults (which the Buddhist clerics tended to disapprove of).

Bottom right are people interested in and knowledgeable about religion, but with a low level of personal participation. I call them 'ethnographers', and I take Yu Yue as a good example. Yu Yue wrote about beliefs, local gods, and rituals at length, yet told us that he himself did not believe or personally engage much in these things.

Finally, bottom left are people both ignorant and aloof from religion: the sceptics. This is likely the category that underwent the greatest growth as Chinese society moved from the late imperial to the Republican period.

\section{Conclusion: changes among the Republican elites}

While I explore twentieth-century changes in elite religiosity in another publication (Katz and Goossaert forthcoming), I would like to make some tentative suggestions here as to how the chart can be used to see changes as gradual and multi-factored rather than revolutionary. Admittedly, the social and political dynamics that created the elite classes changed dramatically as the imperial regime gave way to the Republic. Think for instance of the first Chinese parliament, elected (indirectly, through assemblies of local elites) between December 1912 and January 1913: 60 out of 274 members were Christians (who were still outlaws just two gener- ations earlier) (Goossaert and Palmer 2011: 70). With the end of the civil service examinations in 1905, the criteria for official recruitment changed, to favour modern schools, both civil (many of which were Christian-run) and military.

Besides education, urbanization, and its corollary, the gradual dismantling of the rurally based landlord elite families was also a key factor in the process of change in elite religiosity. It is no coincidence that early Republican-period anti-superstition activists were often people who had cut away from their extended family and country home, and were advocating the 'small family'. Ideas of public and private lives also evolved as a consequence. Why this matters is amply demonstrated by the case study of Yu Yue evoked above. Back in the 189os, Yu could claim both to be a sophisticated literati, removed from an uncough peasantry, sitting in his studio on an island on the West Lake in Hangzhou - the very Mecca of literati refinement - and at the same time to be very well informed indeed about what the spirit-mediums were doing in the villages through his discussions with his servants, daughters-in-law, poorer kin and other relatives who were going there. Similar cases become much harder to find from the 1920 onwards.

Another major correlate of the social developments spurred on by education and urbanization is the increased participation of women in mixedgender religious activities, such as spirit-writing, publishing and lecturing. Late imperial elite women had a large range of religious practices at their disposal, including devotional and self-cultivational practices at home, and some became religious virtuosi teaching their male kin (Liu X. 2015), but their participation in collective religious activities outside the family sphere was always contentious (Goossaert 2008). By the Republican period, the discourse on the 'new woman' was on the one hand claiming to liberate women from the shackles of superstition, but on the other actually giving them more freedom to participate in spirit-writing groups (where they often became very numerous), study groups, mixed-gender sutra recitation groups and other types of public religious organization. ${ }^{6}$

6 For a masterful discussion of modern religious change from a gendered perspective, see Kang 2015. Some spirit-writing groups maintained gender segregation during the Republican period, to show their higher 'moral' standards, but this practice became ever more marginal. 
As a result of these various, mutually reinforcing factors, we see developments unfolding that we can trace on our chart. To sum up our most basic findings, many members of the Republican elites seem rather to lose knowledge of religious culture than to disengage: they move leftward rather than downward in our chart. This, I hasten to add, is a very general trend than tells us nothing about individuals. And all four ideal types are still to be found throughout the twentieth century. There were countless religious activists in Republican China: consider such people as Wang Yiting 王一亭 (1867-1938), a prominent businessman who canvassed for support, organized and funded countless religious organizations, rituals and projects, from the most orthodox monastic Buddhism to a wide assortment of spirit-writing cults and redemptive societies (Katz 2014). Wang and his many friends carried forth the spirit of the engaged layperson. Educated non-committed people were also around. Those local intellectuals in Wenzhou who, well into the early Communist period, wrote down the local customs and found ways around the strictures of atheist orthodoxy to paint them in the best possible light, are fine exemplars of this type (Katz 2015b).

But there is no doubt that the ranks of both fundamentalists and sceptics grew over the fifty years, and beyond into the contemporary era. Many Christians, who wanted to rid China of its superstitions, swelled the ranks of its fundamentalists; so did adepts of a reformed Buddhism. We find representatives of both categories among the nationalist politicians and activists who devised and implemented the anti-superstition policies. Indeed, many elites who rejected traditional Chinese religious culture were not atheists but Christians. Just like Christians, the more numerous elite lay Buddhists also tended to maintain a high level of commitment to their own cultivation while showing a lesser degree of knowledge of 'popular' and local religion.

This raises the last, but not least element of contemporary change in elite religiosity: a trend, certainly not unique to China, towards confessionalization. People who engage with religion tend more and more to identify with one religion (notably, but not exclusively, Buddhism and Christianity) and to adopt practices and lifestyles proper to that religion. This is both a global phenomenon and a mostly unintended effect of the religious policies pursued in the Chinese world since the early twentieth century. Such a trend does not adversely affect overall religiosity, but it does limit personal agency in knowing about and engaging in other practices, and thus building diversity at the individual level.

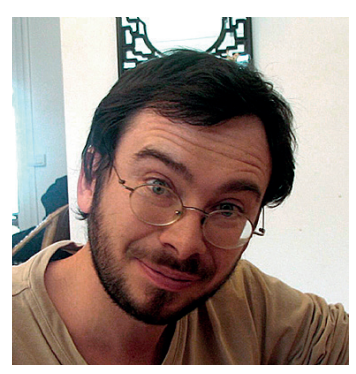

Vincent Goossaert obtained his PhD at EPHE (Ecole pratique des hautes études, 1997), was a research fellow at CNRS (1998-2012) and is now Professor of Daoism and Chinese religions at EPHE. He has been Visiting Professor at the Chinese University of Hong Kong, Geneva University and Renmin University. His research deals with the social history of Chinese religion in late imperial and modern times. He has published books on the Daoist clergy, anticlericalism, Chinese dietary taboos, the production of moral norms, and, with David Palmer, The Religious Question in Modern China (Chicago 2011, Levenson Prize 2013).

Since 2014 he has served as the dean of the EPHE graduate school.

\section{Bibliography}

Burton-Rose, Daniel, 2016. Terrestrial Reward as Divine Recompense: The Self-fashioned Piety of the Peng Lineage of Suzhou, 1650s-1870s, PhD dissertation, Princeton University

Chau, Adam Yuet, 2011. 'Modalities of doing religion', in Chinese Religious Life, eds David A. Palmer, Glenn Shive and Philip L. Wickeri (Oxford University Press), pp. $67-84$

Clart, Philip, 2003. 'Confucius and the Mediums: is there a 'Popular Confucianism'?', T'oung Pao, 89(1-3), pp. $1-38$

-2007. "The concept of "popular religion" in the study of Chinese religions: retrospect and prospects', in The Fourth Fu Jen University Sinological Symposium. Research on Religions in China: Status Quo and Perspectives, ed. Zbigniew Wesolowski (Xinzhuang, Furen Daxue chubanshe), pp. 166-203

Fan Chunwu 范純武, 2010. 'Feiluan, xiuzhen, yu banshan: Zheng Guanying yu Shanghai de zongjiao shijie 飛鸞、修真與辦善：鄭觀應與上海的宗教世 界', in Cong chengshi kan Zhongguo de xiandaixing 從 城市看中國的現代性, ed. Wu Jen-shu 巫仁恕, Lin May-li 林美莉, and Paul R. Katz (Kang Bao 康豹) (Nankang, Institute of Modern History, Academia Sinica), pp. 247-74

-2015. Qingmo minjian cishan shiye yu luantang yundong 清末民間慈善事業與鸞堂運動 (Taipei, Boyang)

Faure, David, 2007. Emperor and Ancestor: State and Lineage in South China (Stanford University Press)

Goossaert, Vincent, 2002a. 'Anatomie d'un discours anticlérical : le Shenbao, 1872-1878, Extrême-Orient Extrême-Occident, 24, pp. 113-31

-2002 b. 'Starved of resources: clerical hunger and 
enclosures in nineteenth-century China', Harvard Journal of Asiatic Studies, 62(1), pp. 77-133

-2006. ' 1898 : the beginning of the end for Chinese religion?', Journal of Asian Studies, 65(2), pp. 307-36

-2007. The Taoists of Peking, 1800-1949: A Social History of Urban Clerics (Cambridge, MA, Harvard University Asia Center)

-2008. 'Irrepressible female piety: late imperial bans on women visiting temples', Nan Nü. Men, Women and Gender in China, 10(2), pp. 212-41

-2011a. 'Daoists in the Modern Chinese self-cultivation market: the case of Beijing, 1850-1949' in Daoism in the 2oth Century: Between Eternity and Modernity, eds David Palmer and Liu Xun (Berkeley, University of California Press), pp. 123-53

-2011b. 'Yu Yue (1821-1906) explore l'au-delà. La culture religieuse des élites chinoises à la veille des révolutions' in Miscellanea Asiatica, eds Roberte Hamayon, Denise Aigle, Isabelle Charleux and Vincent Goossaert (Sankt Augustin, Monumenta Serica), pp. 623-56

-2013. 'A question of control: licensing local ritual specialists in Jiangnan, 1850-1950' in Xinyang, shijian yu wenhua tiaoshi: Proceeding of the Fourth International Sinology Conference 信仰、實踐與文化調適. 第四 屆國際漢學會議論文集, eds Liu Shufen and Paul R. Katz (Taipei, Academia Sinica), pp. 569-604

-2014a. 'Managing Chinese religious pluralism in the nineteenth-century City Gods Temples', in Globalization and the Making of Religious Modernity in China, eds Thomas Jansen, Thoralf Klein, and Christian Meyer (Boston, Brill), pp. 29-51

-2014b. 'Modern Daoist eschatology: spirit-writing and elite soteriology in late imperial China', Daoism. Religion, History \& Society, 6, pp. 219-46

-2015a. 'The shifting balance of power in the City God Temples, late Qing to 1937', Journal of Chinese Religions, 43(1), pp. 5-33

-2015b. 'Spirit-writing, canonization and the rise of divine saviors: Wenchang, Lüzu, and Guandi, 17001858', Late Imperial China, 36(2), pp. 82-125

-2016. 'Guerre, violence et eschatologie. Interprétations religieuses de la guerre des Taiping (1851-1864)' in Guerre et Religion, ed. Jean Baechler (Paris, Hermann), pp. 81-94

-2017. Bureaucratie et salut. Devenir un dieu en Chine (Genève, Labor \& Fides)

Goossaert, Vincent, and David Palmer, 2011. The Religious Question in Modern China (Chicago University Press)

Harrison, Henrietta, 2005. The Man Awakened from Dreams: One Man's Life in a North China Village 1857-1942 (Stanford University Press)

Jordan, David K., and Daniel Overmyer, 1986. The Flying Phoenix: Aspects of Chinese Sectarianism in Taiwan (Princeton University Press)

Kang Xiaofei, 2015. 'Women and the religious question in Modern China', in Modern Chinese Religion II:
1850-2015, eds Vincent Goossaert, Jan Kiely and John Lagerwey (Leiden, Brill), pp. 491-559

Katz, Paul R., 2003. 'Local elites and sacred sites in HsinChuang: the growth of the Ti-tsang An during the Japanese occupation' in Belief, Ritual, and Society: Papers from the Third International Conference on Sinology, Anthropology Section, ed. Lin Mei-rong (Nankang, Institute of Ethnology, Academia Sinica), pp. 179-227

-2014. Religion in China and Its Modern Fate (Waltham, MA, Brandeis University Press)

-2015a. 'Spirit-writing and the dynamics of elite religious life in Republican era Shanghai' in Jindai Zhongguo de zongjiao fazhan lunwenji 近代中國的宗教發展論文集, ed. Ding Renjie 丁仁傑 et al. (Taipei, Guoshiguan), pp. $275-350$

-2015 b. 'Writing a place for rites: the value of "old customs" in modern Wenzhou', Journal of Chinese Religions, 43(1), pp. 59-88

Katz, Paul R. 康豹, and Vincent Goossaert 高萬桑 (eds) 2015. Gaibian Zhongguo zongjiao de wushinian 改變 中國宗教的五十年，1898-1948 (Taipei, Academia Sinica, Institute of Modern History)

Katz, Paul R., and Vincent Goossaert, forthcoming. The Fifty Years that Changed Chinese Religion

Liu Xun, 2004. 'Immortals and patriarchs: the Daoist world of a Manchu official and his family in nineteenth century China', Asia Major, 3rd series, 17(2), pp. $161-218$

-2009. Daoist Modern: Innovation, Lay Practice, and the Community of Inner Alchemy in Republican Shanghai (Cambridge, MA, Harvard University Asia Center)

-2015. 'Of poems, gods, and spirit-writing altars: the Daoist beliefs and practice of Wang Duan (17931839)', Late Imperial China, 36(2), pp. 23-81

Liu Yonghua, 2013. Confucian Rituals and Chinese Villagers: Ritual Change and Social Transformation in a Southeastern Chinese Community, 1368-1949 (Leiden, Brill)

Meyer-Fong, Tobie, 2013. What Remains: Coming to Terms with Civil War in 19th Century China (Stanford University Press)

Naquin, Susan, 2000. Peking. Temples and City Life, 14001900 (Berkeley, University of California Press)

Palmer, David A., 2011. 'Gift and market in the Chinese religious economy', Religion, 41(4), pp. 569-94

Schmidt-Leukel, Perry, and Joachim Gentz (eds), 2013. Religious Diversity in Chinese Thought (New York, Palgrave Macmillan)

Sutton, Donald, 200o. 'From credulity to scorn: Confucians confront the spirit mediums in late imperial China, Late Imperial China, 21(2), pp. 1-39

-(ed.), 2007. Special issue 'Ritual, Cultural Standardization, and Orthopraxy in China: Reconsidering James L. Watson's Ideas', Modern China 33(1)

Szonyi, Michael, 2002. Practicing Kinship: Lineage and Descent in Late Imperial China (Stanford University Press) 
Wang Chien-ch'uan 王見川, 2012. 'Qingmo de guanshen yu fuji: jiantan qishi liuxing de chenyan 清末的官 紳與扶乩. 兼談其時流行的讖言', Mazu yu minjian xinyang: yanjiu tongxun 媽祖與民間信仰：研究通訊， 2, pp. 34-47

-2015. 'Spirit-writing groups in Modern China (18401937): textual production, public teachings, and charity', trans. Vincent Goossaert, in Modern Chinese Religion: 1850-2015, ed. Vincent Goossaert, Jan Kiely and John Lagerwey (Leiden, Brill), pp. 651-84

Yang Fenggang, 2012. Religion in China: Survival and Revival under Communist Rule (New York, Oxford Universsity Press)

Yau, Chi-on (You Zian) 游子安, 2005. Shan yu ren tong. Ming Qing yilai de cishan yu jiaohua 善與人同: 明清 以來的慈善與教化 (Beijing, Zhonghua shuju) 